\title{
Evaluation of Lung Function Changes Before and After Surfactant Application During Artificial Ventilation in Newborn Rats With Congenital Diaphragmatic Hernia
}

\author{
By E.C. Scheffers, H. IJsselstijn, R. Tenbrinck, B. Lachmann, J.C. de Jongste, J.C. Molenaar, and D. Tibboel \\ Rotterdam, The Netherlands
}

\begin{abstract}
- Patients with congenital diaphragmatic hernia (CDH) have unilateral or bilateral hypoplasia of the lungs including delayed maturation of the terminal air sacs. Because these lungs are highly susceptible to barotrauma and oxygen toxicity, even in full-term newborns, continued research into optimal ventilatory regimen is essential to improve survival rate and to prevent ongoing lung damage. Against this background, the effect of exogenous surfactant application is evaluated. In newborn rats, CDH was induced after a single dose of 2,4 dichloro-4'-nitrophenyl (Nitrofen) $(400 \mathrm{mg} / \mathrm{kg}$ ) on day 10 of gestation. The newborn rats were intubated immediately after hysterotomy, transferred to a heated multichambered body plethysmograph, and artificially ventilated. Inspiratory peak pressures were initially set at $17 \mathrm{~cm}$ $\mathrm{H}_{2} \mathrm{O}$, with positive end-expiratory pressure at $\mathrm{O} \mathrm{cm} \mathrm{H}_{2} \mathrm{O}$ and $\mathrm{FiO}_{2}$ at 1.0. The pressure was raised in steps of $5 \mathrm{~cm} \mathrm{H}_{2} \mathrm{O}$, from 5 to $30 \mathrm{~cm} \mathrm{H} \mathrm{H}_{2} \mathrm{O}$, to obtain pressure-volume diagrams at 0,1 . and 6 hours of artifical ventilation. These measurements were obtained in controls and in $\mathrm{CDH}$ rats with and without endotracheal installation of bovine surfactant $(n=4$ to 10 in each group). Significant differences in lung volume between $\mathrm{CDH}$ and control rats were observed at all time-points. Surfactant application had a positive effect on lung volume, especially in control rats at $t=1$ hour. No significant differences were observed between the CDH groups at $t=1$ or $t=$ 6 hours. In this animal model, the effect of artificial ventilation as well as the beneficial short-term effect of exogenous surfactant application have been evaluated. A continued positive effect on lung volume in CDH lungs could not be determined. Routine administration of exogenous surfactant in human CDH patients is not supported by these experimental results.
\end{abstract}

Copyright $(1994$ by W.B. Saunders Company

INDEX WORDS: Diaphragmatic hernia, congenital, newborn, artificial ventilation, pulmonary hypoplasia, surfactant.

$\mathbf{I}^{\mathrm{N}}$ N PATIENTS who have congenital diaphragmatic hernia (CDH), abnormal morphological development of both lungs and the intrapulmonary blood

From the Departments of Paediatric Surgery and Paediatric Pulmonology, Sophia Children's Hospital, Rotterdam, The Netherlands, and the Department of Experimental Anaesthesiology, Erasmus University, Rotterdam, The Netherlands.

Presented at the 40th Annual Intemational Congress of the British Association of Paediatric Surgeons, Manchester, England, July 21-23, 1993.

Supported by the Sophia Foundation for Scientific Research and the Dutch Astma Foundation.

Address reprint requests to Professor Dr D. Tibboel, Department of Paediatric Surgery, Sophia Children's Hospital, Gordelweg 160, 3038 GE Rotterdam, The Netherlands.

Copyright $\odot 1994$ by W.B. Saunders Company

0022-3468/94/2906-0027\$03.0010 vessels is present..$^{1-5}$ However, reports on the biochemical maturation of the lung in $\mathrm{CDH}$ are scarce.

Hisanaga et $\mathrm{a}^{6}$ noted low lecithin:sphingomyelin ratios ( 0.56 and 0.57 , respectively) in two infants with $\mathrm{CDH}$. They argued that lung hypoplasia actually means a reduced number of type II pneumocytes and reduced production of surfactant. The lecithin: sphingomyelin ratio reflects to some extent the maturation of the fetal lung. However, the question remains: are the ratios low because of the total reduction in lung tissue or because the type II cell in $\mathrm{CDH}$ functions at a lower level??

Hashimoto et $\mathrm{al}^{8}$ investigated the morphological characteristics of the type II cell in a fetal lamb model of CDH. Surprisingly, they found that type II cells were 5 to 10 times more abundant in the lungs of animals with a diaphragmatic defect. No ultrastructural changes of immaturity were observed in type II cells.

Glick et $\mathrm{al}^{9}$ studied lung surfactant production in the fetal lamb after experimental induction of CDH and showed (1) a marked decrease in pulmonary compliance, (2) a reduction of the total amount of phospholipid in bronchoalveolar lavage fluid, and (3) a reduction in the synthesis rate of phosphatidylcholine by type II cells. The authors concluded that $\mathrm{CDH}$ in the fetal lamb leads to profound lung hypoplasia and apparent immaturity of the surfactant system.

In neonatal rats, $\mathrm{CDH}$ can be induced by feeding of 2,4 dichloro-4' -nitrophenyl ether (Nitrofen, Rohm \& Haas Co, Philadelphia, PA) to the mothers during gestation, as documented previously. ${ }^{10-12}$ In this model, the lungs of $\mathrm{CDH}$ animals showed hypoplasia and lower content of disaturated phosphatidylcholine per microgram DNA and total disaturated phosphatidylcholine, as shown by Suen. ${ }^{13}$

The conflicting results obtained in different animal models has guided us to investigate the effect of exogenous surfactant application in relation to changes in lung volume after artificial ventilation in newborn rats with $\mathrm{CDH}$.

\section{MATERIALS AND METHODS}

Female Sprague Dawley rats (Harlan, Zeist, The Netherlands) weighing 240 to $280 \mathrm{~g}$ were mated during 1 hour (day 0 of gestation). On day 10 of gestation, $100 \mathrm{mg}$ of 2.4 dichloro-4'nitrophenyl ether (Nitrofen), dissolved in $1 \mathrm{~mL}$ of olive oil, was 
administered by gastric tube to the Nitrofen group; controls received $1 \mathrm{~mL}$ of olive oil. Food and water were supplied ad libitum during the entire period. Hysterotomy was performed on gestational day 22

The animals born spontaneously were excluded from the experiment because the period of spontaneous breathing could not be determined in detail and would influence lung function parameters. There were three groups of newborns: controls, animals with a diaphragmatic hernia, and animals without a diaphragmatic defect after Nitrofen administration (10\%-20\% of the animals receiving Nitrofen).

Before the hysterotomy, the dam was anaesthetized with $\mathrm{N}_{2} \mathrm{O}$ and enflurane-inhalation, and the fetuses were delivered. Immediately after hysterotomy, the newborns were weighed and received pancuronium bromide $(0.08 \mathrm{mg} / \mathrm{kg}$ each second hour) and pentobarbital ( $40 \mathrm{mg} / \mathrm{kg}$ each third hour) intraperitoneally, followed by intubation with a metal canula. The cannulas used throughout the experiment were made from syringe needles (internal diameter, 0.5 $\mathrm{mm}$; external diameter, $0.7 \mathrm{~mm}$ ).

The intubated animals were immediately transferred to a multichambered, pressure-constant body plethysmograph heated to $38^{\circ} \mathrm{C}$. This procedure lasted 1 to 2 minutes for each animal. A flexible tube provided an adequate connection between the trachea and the body-box. The maximum number of ventilated animals per litter was nine.

\section{Artificial Ventilation}

The body plethysmograph was connected to a modified ventila tor (Servo 900B; Siemens-Elema, Solna, Sweden), as routinely used in the I.C.U., and as described by Lachmann et al. ${ }^{14}$ This equipment provides pressure-generated ventilation with decelerating flow, using excess flow through the ventilator system.

The ventilator settings throughout the experiment were as follows: $\mathrm{FIO}_{2}, 1.0$; frequency, 40/min; $\mathrm{I}: \mathrm{E}$ ratio, $1: 2$; inspiratory peak pressure, $17 \mathrm{~cm} \mathrm{H}_{2} \mathrm{O}$; positive end-expiratory pressure (PEEP), $0 \mathrm{~cm}$. These settings were changed only to obtain pressure-volume relations, ie, the pressures were raised from $7 \mathrm{~cm} \mathrm{H}_{2} \mathrm{O}$, in steps of approximately $5 \mathrm{~cm} \mathrm{H}_{2} \mathrm{O}$, to a maximum of $30 \mathrm{~cm} \mathrm{H}_{2} \mathrm{O}$. The other settings remained the same throughout the experiments. The pressure-volume relations were determined for each fetus with a specially designed Fleisch-tube ${ }^{14}$ connected to the body plethysmograph. a differential pressure transducer (EMT 34; (Siemens-
Elema) and amplifier (EMT 31), an integrator unit (EMT 41), and a recorder Mingograf 81 ; Siemens-Elema ).

The animals were ventilated for a maximum of 6 hours. Pressurevolume relations were determined at 0,1 , and 6 hours. Zero hours applied to the animals that were intubated immediately after hysterotomy because they showed no signs of spontaneous breathing.

The animals without visible heart action, pneumothorax, or other complications related to insufficient ventilation or technical problems were excluded from the study. The same holds true for animals without $\mathrm{CDH}$ after Nitrofen administration and those with huge diaphragmatic defects that died less than 6 hours after birth. After the experiments, the animals were killed by an overdose of pentobarbital.

\section{Surfactant Application}

After intubation and the start of artificial ventilation (with peak

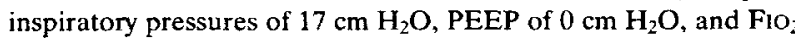
of 1.0), both control and Nitrofen animals received either a bolus of bovine surfactant $(0.05 \mathrm{~mL}$ of a $25-\mathrm{mg} / \mathrm{mL}$ solution) or nothing. Pressure-volume diagrams were obtained as described before, at $\mathrm{t}=1$ and $\mathrm{t}=6$ hours

\section{Calculations}

By means of the measured pressure-volume points, a pressurevolume curve was plotted for each animal at each time-point. The volume at the standardized pressures of $7,10,15,20,25$, and $30 \mathrm{~cm}$ $\mathrm{H}_{2} \mathrm{O}$ was determined from these curves and recorded. For each group, the means of volume were calculated at standardized pressures. These means were compared, and statistical significance was determined by means of the Mann-Whitney or Student's $t$ test.

\section{RESULTS}

For each group, the values of lung volume at the peak pressures of 15 and $25 \mathrm{~cm} \mathrm{H}_{2} \mathrm{O}$ (with standard deviation) as well as the number of animals at each time-point are shown in Table 1. Representative pressure-volume diagrams are shown in Figs 1 and 2.

Table 1. Pressure / Volume Relations in Control and CDH Rats at Different Times, With or Without Exogenous Surfactant

\begin{tabular}{|c|c|c|c|c|c|c|c|c|c|c|}
\hline \multirow{3}{*}{$\begin{array}{c}\text { Time } \\
\text { (hours) }\end{array}$} & \multicolumn{5}{|c|}{ Control } & \multicolumn{5}{|c|}{ Hernia } \\
\hline & & \multicolumn{2}{|c|}{ No Surfactant } & \multicolumn{2}{|c|}{ Surfactant } & & \multicolumn{2}{|c|}{ No Surfactant } & \multicolumn{2}{|c|}{ Surfactant } \\
\hline & & $15 \mathrm{~cm} \mathrm{H}_{2} \mathrm{O}$ & $25 \mathrm{~cm} \mathrm{H}_{2} \mathrm{O}$ & $15 \mathrm{~cm} \mathrm{H}_{2} \mathrm{O}$ & $25 \mathrm{~cm} \mathrm{H} \mathrm{H}_{2} \mathrm{O}$ & & $15 \mathrm{~cm} \mathrm{H}_{2} \mathrm{O}$ & $25 \mathrm{~cm} \mathrm{H}_{2} \mathrm{O}$ & $15 \mathrm{~cm} \mathrm{H}_{2} \mathrm{O}$ & $25 \mathrm{~cm} \mathrm{H}_{2} \mathrm{O}$ \\
\hline \multirow[t]{4}{*}{0} & Mean & 24.8 & 81.4 & - & - & Mean & 5.9 & 22.4 & - & $\ldots$ \\
\hline & So & 17.6 & 32.1 & & & SD & 5.5 & 23.6 & & \\
\hline & $n$ & 15 & & & & $n$ & 9 & & & \\
\hline & Significance & & & & & Significance & $\#$ & $\#$ & & \\
\hline \multirow[t]{4}{*}{1} & Mean & 109.8 & 160.4 & 108.6 & 216.9 & Mean & 34.1 & 95.3 & 26.9 & 83.5 \\
\hline & SD & 34.9 & 41.1 & 59.2 & 61.9 & $S D$ & 13.9 & 38.2 & 17.1 & 20.6 \\
\hline & $n$ & 9 & & 12 & & $\mathrm{n}$ & 6 & & 6 & \\
\hline & Significance & $\underline{a}$ & a & (a) & $(\underline{Q}) *$ & Significance & (a\# & $(a \#$ & $(a t \#$ & $(a) \#$ \\
\hline \multirow[t]{4}{*}{6} & Mean & 141.3 & 165.1 & 146.5 & 190.4 & Mean & 41.6 & 87.8 & 44.9 & 85.6 \\
\hline & so & 50.8 & 63.3 & 45.9 & 61.5 & SD & 27.3 & 25.3 & 30.4 & 38.6 \\
\hline & $n$ & 8 & & 10 & & $\mathrm{n}$ & 6 & & 4 & \\
\hline & Significance & $a$ & a & $(a$ & $\underline{a}$ & Significance & $(a \#$ & (u:\# & $(a) \#$ & $(a \#$ \\
\hline
\end{tabular}

NOTE. For all values, $P<5 \%$.

Abbreviations: @, significant from T - 0 in the same group; *, significant from the same group without surfactant; \#, significant from control at the same time. 
control

$t=0$

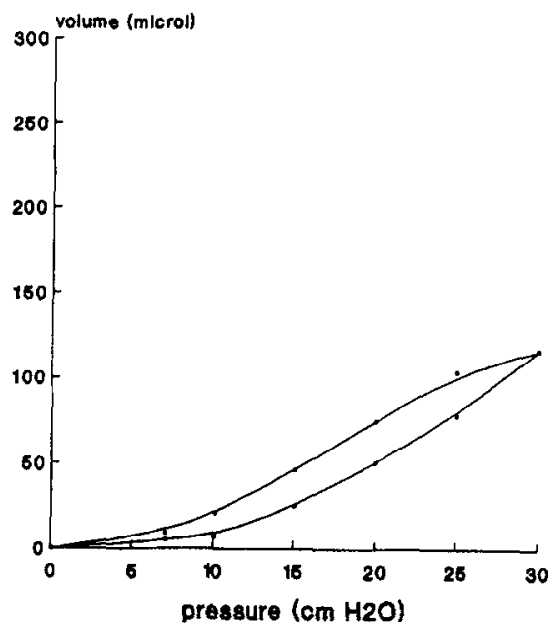

control

$t=1$, no treatment

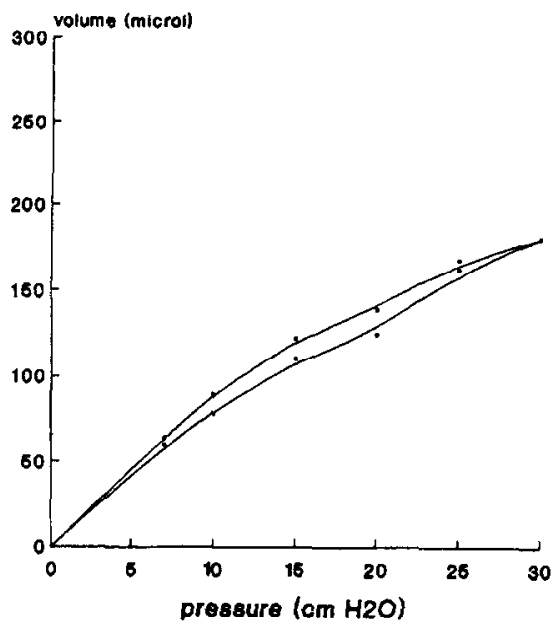

control

$t=1$, surfactant

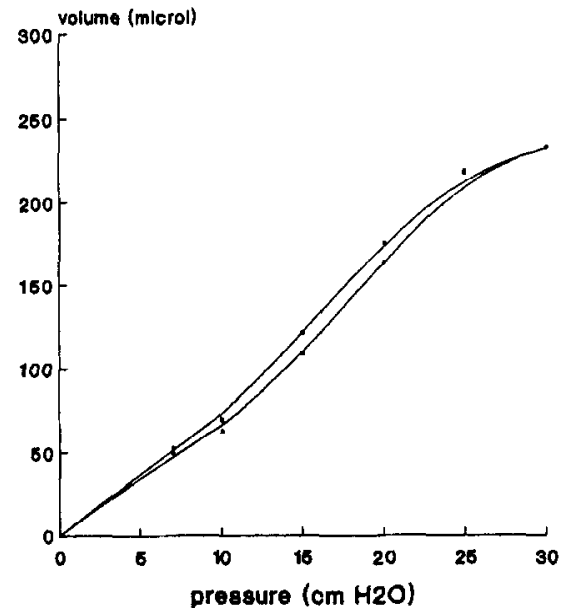

$\mathrm{CDH}$

$\mathrm{t}=0$

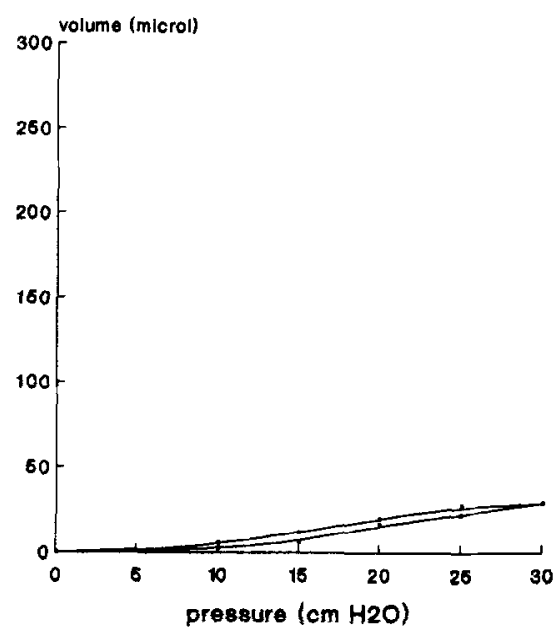

$\mathrm{CDH}$

$t=1$, no treatment

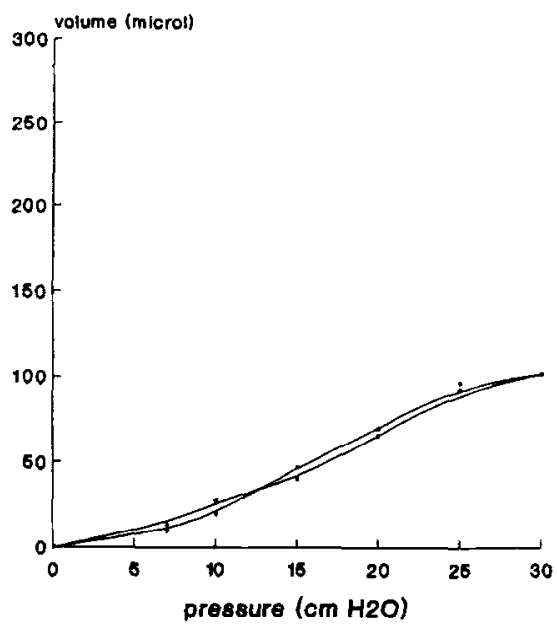

$\mathrm{CDH}$

$t=1$, surfactant

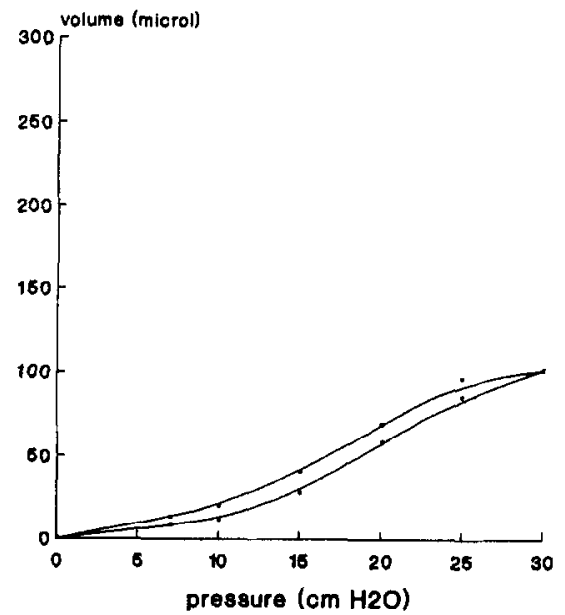

Fig 1. Rapresentative pressure-volume curves at $t=0$ and $t=1$ in control rats, CDH rats without treatment, and CDH rats with surfactant. 
control $t=6$, no treatment

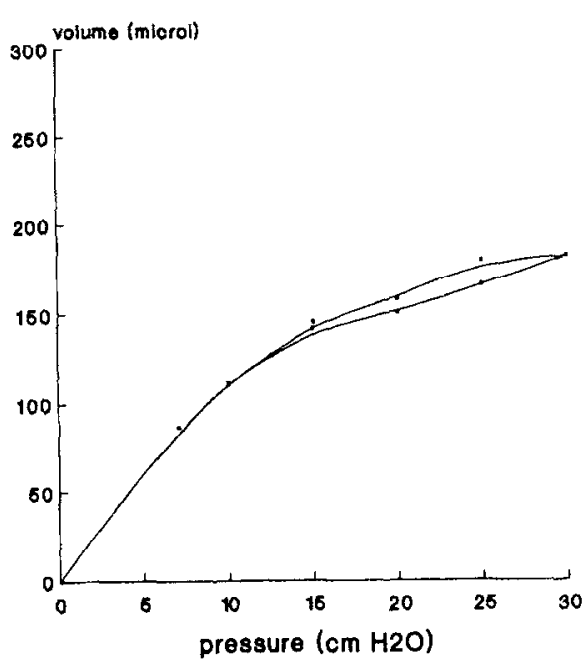

Fig 2. Representative pressurevolume curves at $t=6$ in control rats, $\mathrm{CDH}$ rats without treatment, and $C D H$ rats with surfactant. control $t=6$, surfactant
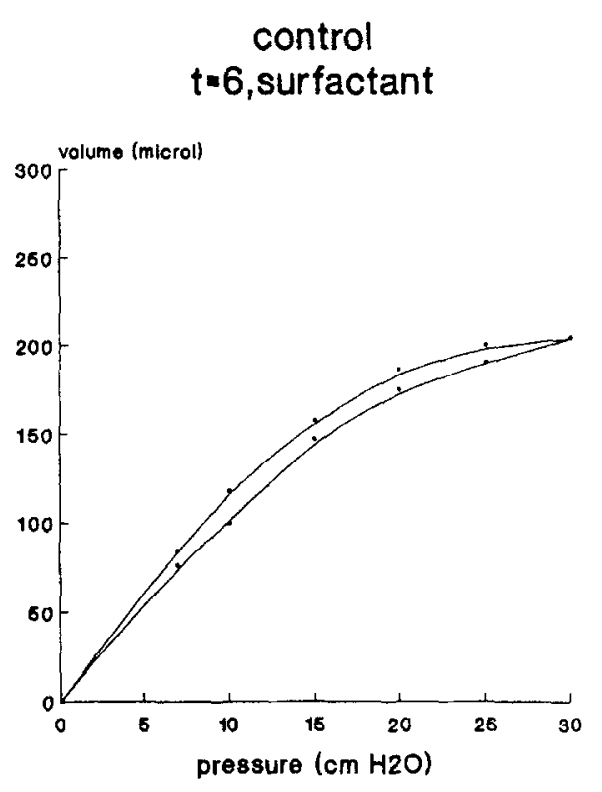

$\mathrm{CDH}$

$t=6$, no treatment

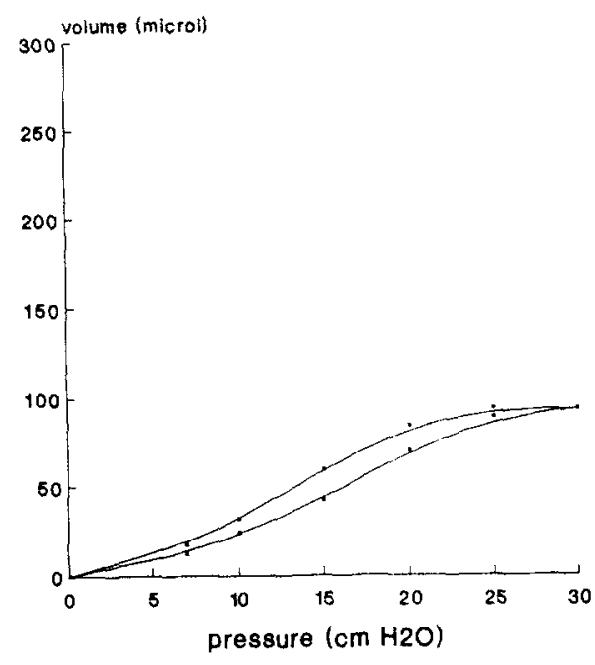

$\mathrm{CDH}$

$t=6$, surfactant

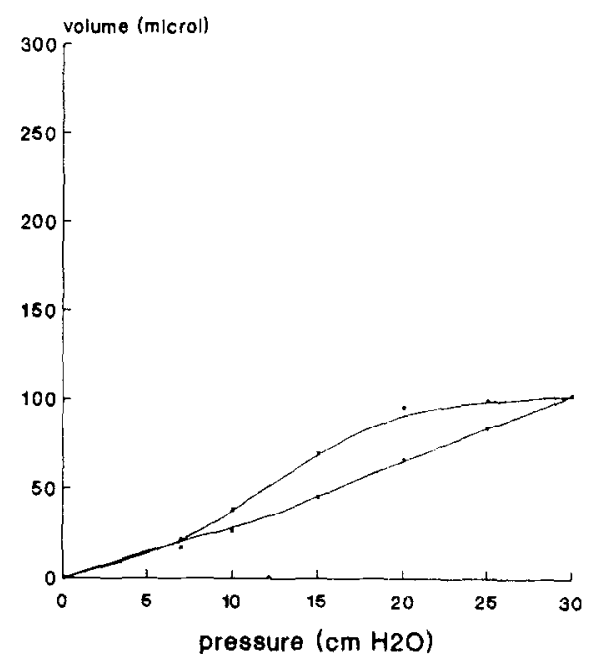

There are significant differences for each time-point between control and $\mathrm{CDH}$ rats, with $\mathrm{CDH}$ rats having lower lung volumes.

The effect of superfactant application is greater in controls than in $\mathrm{CDH}$ rats. A positive effect of surfactant application in control rats was found at $\mathrm{t}=$ 1 hour. There were no significant differences at $t=1$ or $t=6$ hours between the $\mathrm{CDH}$ groups.

\section{DISCUSSION}

\section{Animal Data}

Our study shows not only that artificial ventilation of neonatal rats is possible but also that the effect of exogenous surfactant application can be studied in detail. Following the classic approach of inducing CDH in sheep (by Harrison et $\mathrm{al}^{15}$ ), Hashimoto et $\mathrm{al}^{8}$ investigated the morphological characteristics of the type II cell in a fetal lamb model of CDH. Surprisingly, they found that type II cells were 5 to 10 times more abundant in the lungs of animals having a diaphragmatic defect. No ultrastructural changes of immaturity were observed in type II cells.

In contrast to the above-mentioned study, various other research groups have documented or suggested that in the hypoplastic lungs of CDH rats, immaturity of the lungs exists. ${ }^{12,13,16}$ Sucn et al, ${ }^{13}$ using whole-lung homogenates, noted significantly lower desaturated phosphatidylcholine (DSPC) per microgram DNA 
and total DSPC in CDH rats, and Brandsma et al, ${ }^{16}$ using bronchoalveolar lavages of control and $\mathrm{CDH}$ rats, came to the same conclusion. Recently, Suen et $\mathrm{a}^{17}$ documented the positive effect of antenatal glucocorticoid treatment on the DSPC content of wholelung homogenates in rats with Nitrofen-induced $\mathrm{CDH}$.

The reason we were not able to demonstrate a continuing positive effect on lung volume in $\mathrm{CDH}$ rats might be related to the method of delivery, dosage, timing, or volume of surfactant application; the effect of introducing PEEP should be determined as well.

\section{Human Data}

Increasing evidence shows that the hypoplastic lung in $\mathrm{CDH}$ is developmentally retarded. ${ }^{1-3} \mathrm{~A}$ lower lecithin-sphingomyelin $(\mathrm{L} / \mathrm{S})$ ratio in the amniotic fluid $^{6}$ as well as morphological findings showing hyaline membranes in full-term infants with $\mathrm{CDH}$ emphasize the significance of a further characteriza- tion of the developing terminal lung unit in these patients. For a patient with $\mathrm{CDH}$, accurate determination of the presence of a surfactant deficiency, either primary or secondary, will be of great significance in the selection of appropriate treatment modalities. ${ }^{18}$ Moreover, the high incidence of bronchopulmonary dysplasia in surviving patients ${ }^{19}$ might be prevented by early administration of surfactant, either prophylactically or therapeutically, as has been shown for premature infants with respiratory distress syndrome. ${ }^{20}$

Treatment of $\mathrm{CDH}$ can be individualized by using standard procedures such as bronchoalveolar lavages, as documented by Stenmark et al, ${ }^{21}$ newborns with persistent pulmonary hypertension, to detect surfactant deficiency. Prospcctivc randomized trials in CDH patients, using exogenous surfactant as either prophylaxis or rescue therapy, should be undertaken in the near future to test the value of this approach.

\section{REFERENCES}

1. Wigglesworth JS, Desai R, Guerrini P: Fetal lung hypoplasia: Biochemical and structural variations and their possible significance. Arch Dis Child 56:606-615, 1981

2. Gcorge DK, Cooncy TP, Chiu BK, et al: Hypoplasia and immaturity of the terminal lung unit (acinus) in congenital diaphragmatic hernia. Am Rev Respir Dis 136:947-950, 1987

3. Nakamura Y, Yamamoto I, Fukuda S, et al: Pulmonary acinar development in diaphragmatic hernia. Arch Pathol Lab Med 115:372-376, 1991

4. Levin DL: Morphologic analysis of the pulmonary vascular bed in congenital left-sided diaphragmatic hernia. J Pediatr 92:805809,1978

5. Geggel RL, Murphy JD, Langleben D, et al: Congenital diaphragmatic hernia: Arterial structural changes and persistent pulmonary hypertension after surgical repair. J Pediatr 107:457464,1985

6. Hisanaga S, Shimokawa H, Kashiwabara Y, et al: Unexpectedly low lecithin/sphingomyelin ratios associated with fetal diaphragmatic hernia. Am J Obstet Gynecol 89:905-906, 1984

7. Kikkawa Y, Motoyama EK, Cook CD: The ultrastructure of the lungs in lambs: The relation of osmiophilic inclusions and alveolar lining layer to fetal maturation and experimentally produced respiratory distress. Am J Pathol 47:877-879, 1965

8. Hashimoto EG, Pringle KC, Soper RT, et al: The creation and repair of diaphragmatic hernia in fetal lambs: Morphology of the type II alveolar cell. J Pediatr Surg 20:354-356, 1985

9. Glick PL, Stannard VA, Leach CL, et al: Pathophysiology of congenital diaphragmatic hernia II: The fetal lamb CDH model is surfactant deficient. J Pediatr Surg 27:382-388, 1992

10. Tenbrinck R, Tibboel D, Gaillard JLJ, et al: Experimentally induced congenital diaphragmatic hernia in rats. $J$ Pediatr Surg 25:426-429, 1990

11. Kluth D, Kangah R, Reich R, et al: Nitrofen-induced diaphragmatic hernia in rats: An animal model. J Pediatr Surg $25: 850-854,1990$
12. Alfonso LF, Vilanova $\mathbf{J}$, Aldazabal $\mathbf{P}$, et al: Lung growth and maturation in the rat model of experimentally induced congenital diaphragmatic hernia. Eur J Pediatr Surg 3:6-11, 1993

13. Suen HC, Catlin EA, Ryan DP, et al: Biochemical immaturity of lungs in congenital diaphragmatic hernia. J Pediatr Surg 28:471-477, 1993

14. Lachmann B, Grossman G, Freyse J, et al: Lung-thorax compliance in the artificially ventilated premature rabbit neonate in relation to variations in inspiration:expiration ratio. Pediatr Res 19:833-838, 1981

15. Harrison MR, Jester JA, Ross NA: Correction of congenital diaphragmatic hernia in utero: $\mathrm{I}$. The model: Intrathoracic balloon produces fatal pulmonary hypoplasia. Surgery 88:174-182, 1980

16. Brandsma A, Tibboel D, Vulto IM: Ultrastructural features of alveolar epithelial cells in the late fetal pulmonary acinus; A comparison between normal and hypoplastic lungs, using a rat model of pulmonary hypoplasia and congenital diaphragmatic hernia. Micros Res Techn 26:389-399, 1993

17. Suen HC, Bloch D, Donahoe PK: Antenatal glucocorticoid treatment corrects the pulmonary immaturity of congenital diaphragramatic hernia. J Pediatr Surg (in press)

18. Bos AP, Tibboel D, Hazebroek FWJ, et al: Surfactant replacement therapy in high-risk congenital diaphragmatic hernia. Lancet 338:1279, 1991 (letter)

19. Bos AP, Hussain SM, Hazebroek FWJ, et al: Radiographic evidence of bronchopulmonary dysplasia in high-risk congenital diaphragmatic hernia survivors. Pediatr Pulmonol 15:231-234, 1993

20. Jobe AH: Pulmonary surfactant therapy. N Engl J Med 328:861-868, 1993

21. Stenmark KR, James SL, Voelkel NF, et al: Leukotriene $\mathrm{C}_{4}$ and $\mathrm{D}_{4}$ in neonates with hypoxemia and pulmonary hypertension. N Engl J Med 309:77-80, 1983 